\title{
Students' Perception of Cell Phones in the Classroom
}

\author{
Kimbrough, $\mathrm{S}^{1}$, Culpepper, $\mathrm{D}^{1}$, Crutcher, $\mathrm{T}^{1}$ \\ ${ }^{1}$ Texas A\&M University-Commerce
}

*Corresponding Author: Culpepper, D, Texas A\&M University-Commerce

\begin{abstract}
College students spend the majority of their day on a cellphone both during school and at home. Cellphone use during class is related to lower test scores and distraction. Banning cellphones in the classroom may not be possible nor feasible. The purpose of this study was to assess the students' perceptions about offering positive reinforcement for not using cellphones in class and the effects it has on classroom atmosphere. Results showed that $96 \%$ of students felt it was a positive experience and would recommend it for future courses. The students felt more engaged, focused, and improved concentration. While cellphone addiction is real and causes distractions, offering positive reinforcement to surrender a cellphone is suggested to improve classroom atmosphere, attention, and focus.
\end{abstract}

\section{INTRODUCTION}

The typical college student spends between eight and ten hours a day on his/her cellphone (Roberts \& Williams, 2016). These students spend the majority of the time texting, followed by email, Facebook, web browsing, and listening to music. Students describe their phone as a "warm blanket" that helps them stay connected and not miss an update or "like" (Cohan, 2016). Cohan also reported that students will reject plans with friends so that they can "stay with their phone" (2016). The cellphone is less of a phone when the person can play games, shop, watch movies, and access anything in the world. Obsessive cellphone use is a problem (Roberts \& Williams, 2016) and these types of activities now stretch into the classroom with more than $95 \%$ of students reporting using their phone during class (McCoy, 2013). And why not, students have ready access to a mini-supercomputer to help with work (Barnwell, 2016). This change from a simple phone to a computer has changed the way we look at phones in the classroom. This in turn has changed the attitudes toward their use in class.

In the early 2000's cellphones were banned in over $79 \%$ of all classes (K-university), with that number moving to $69 \%$ of teachers supporting the use of phones in class now (Thomas, O'Bannon \& Bolton, 2013). It is now common to have phones across grade levels from middle, high, and university (Kowalski, 2016). Cellphones and devices bring "meaningful learning opportunities from anywhere" (Traxler, 2009) and afford the creation of student-centered learning, collaboration, and assessment (Thomas, K., O’Bannon, B.W., \& Britt, V., 2014). Teachers have found that students have an invested interest in learning about the features of their phone and using this interest helps extend learning outside of the confines of the class period (Ormiston, 2016). There are multitudes of apps and programs that allow curriculum materials to be delivered digitally and across platforms that can differentiate instruction and learning. In addition to these benefits, there are documented barriers.

The downside of phones in the classroom is that they cause distractions. Students who are allowed to engage on the phones during lectures score between 63-67\% less than students who are not allowed to engage on their phones (Kuznekoff, 2015). There is a growing body of research to support that allowing phones in the classroom leads to lower grades and GPA (Burak, 2012, Duncan, Hoekstra, \& Wilcox, 2012, McDonald, 2013, \& Kuznekoff, 2015). While it would seem that the best approach would be an outright ban, this would be counterproductive in some areas.

Universities and colleges send emergency messages and bulletins via texts and apps to warn students of dangerous situations where they must seek shelter. Faculty argue that phones are needed in class for activities to prepare for their future profession and to become competent in an ever-changing technology-driven world (Katz \& Lambert, 2016). In addition, phones and tablets can help students organize notes, help with math problems, and reduce the need for heavy paper texts. Mobile devices allow students to be connected with the professional world around them during lectures. Students 
must also learn how to become tech-savvy, and what that means to their future profession. Limiting the distraction that cellphones cause in the classroom is a debate that at times seems like polar opposites (APA, 2017). Punishing the use of a phone in the class may not be advisable either since taking a cellphone away may cause significantly worse problems than an instructor anticipates. In recent months, students have become physical with teachers trying to enforce this policy (Song, J. \& Blume, H., 2015) and this type of behavior punishment is not in the best interest of the student nor the teacher.

Psychologists have repeatedly stated that punishment is not effective in encouraging desired behaviors (Katz \& Lambert, 2016). In addition, merely stating in a syllabus that the use of cellphones is not permitted can cause the use of the phone to undermine the instructor during the course of the year (McDonald, 2013). Conversely, many researchers have pointed out that students have become addicted to their phones (Burak, 2012) and continuously check texts, social media accounts, and web surf. This can cause anxiety and frustration (Elhai, Dvorak, Levine, \& Hall, 2017) when taken away. Cellphone addiction is a modern phenomenon and must be taken into account when banning their use in classes. This behavioral disorder means that it is difficult to get students to stop their behavior even if they know that the phone is a problematic.

Katz \& Lambert (2016) studied the use of positive reinforcement, in the form of extra credit, to promote the use of not using a phone during class. Their study showed that, while correlational, students' total test scores were higher when they surrendered their phone. One of the drawbacks of their study was that student perceptions of not having a cellphone in the class were not evaluated. While the assumption is that students always want their phone, research has not been clear whether this is accurate or not (Katz \& Lambert, 2016; Gardiner, 2016; Berry \& Westfall, 2015). There is very little doubt that cellphones are distracting and the growing body of literature suggests that cellphones lower test scores, but what do the students consider? The purpose of this study was to assess the students' perceptions about offering positive reinforcement for not using cellphones in class and effects it has on classroom atmosphere.

\section{METHODS}

Thirteen university courses participated in the study. Students were instructed that they would receive additional credit to their course grade (up to $2 \%$ ) if they chose to put their cellphone in a designated spot in the room and be unable to access it during the class. Additionally, students who chose to do this were required to place their phone on airplane mode or power it down completely, so that "silenced" phones would not distract others when buzzing at the receipt of a text message or email. When class was over, students could retrieve their phones. Students had the option every class to keep their phones or place them at the front to earn the extra credit points. This went on each day the class met, and at the end of the semester, the students were asked to complete a questionnaire about their experience (see Appendix A).

\section{Results}

Two-hundred and twenty-eight students completed the questionnaire. Frequency data is presented in table one and table two for the survey.

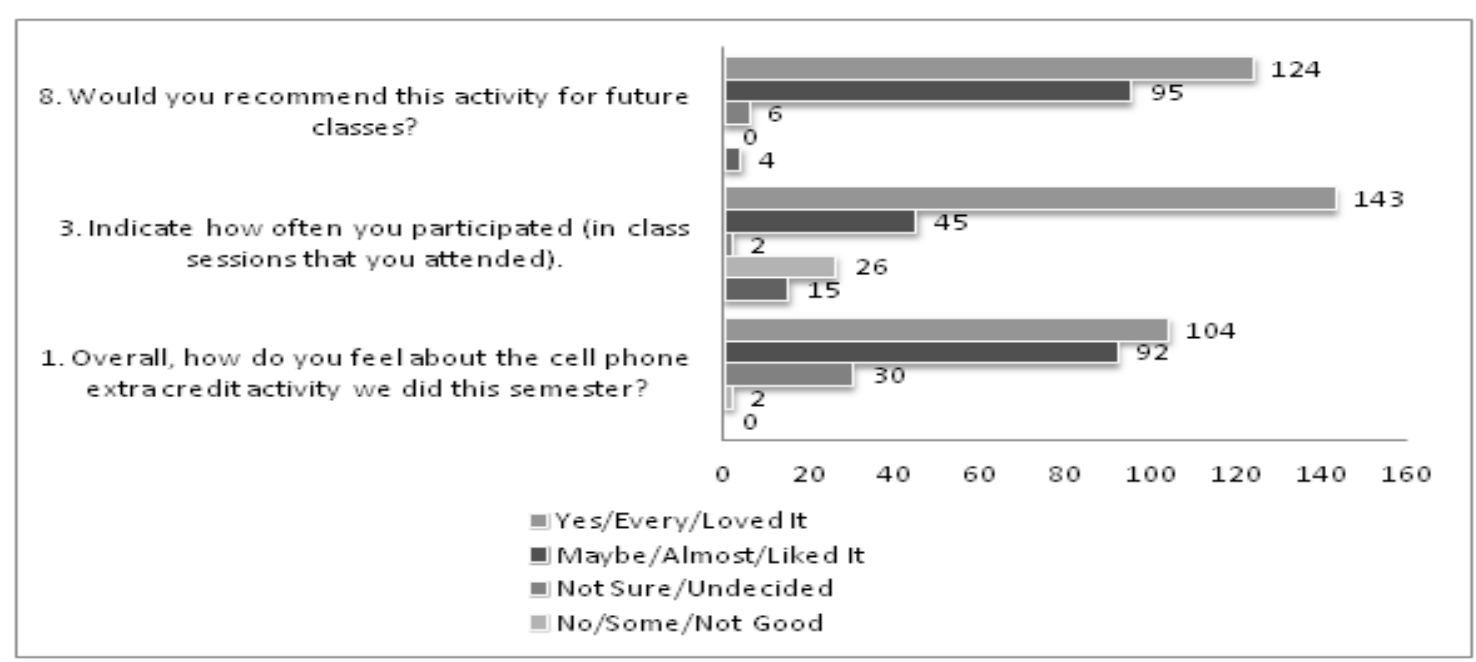


6. Did you feel the class participating in the cell phone extra credit changed the classroom atmosphere to be more respectful?

5. Did you feel the class participating in the cell phone extra cre dit changed the classroom atmosphere to be more focused?

4. Did the class participating in the cell phone extracredithelp you concentrate better on classroom activities?

2. Do you feel it had an overall positive effect on the classroom atmosphere in general?

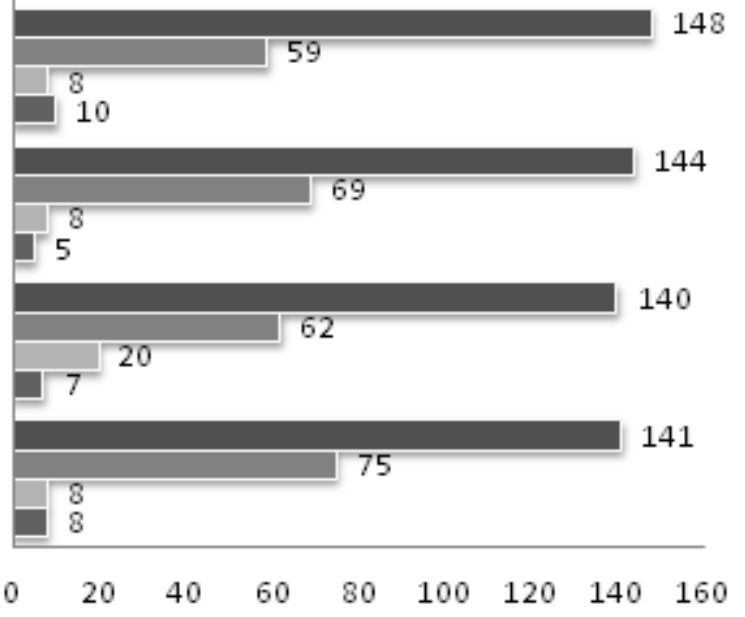

घtrongly Agree $\square$ Agree $\square$ Disagree $\square$ Undecided

The open-ended responses to the cellphone questionnaire (\#7) were recorded and then analyzed. These reactions yielded four themes. The themes are presented in table 3 . Theme one represents the idea that the students just didn't care to participate in the extra credit activity of turning in their cellphone each class time. Theme two represents the student wanting/needing their phone for personal and/or family issues (e.g., children) or if an emergency arose. Theme three expresses the idea that participating in the activity would not earn them enough extra credit to help their grade and the student stopped participating. The final one, theme four, represents that the student just wanted their phone with them during class to do other things on it.

Table3. Themes of Open Ended Question Responses (\#7) to Why Individuals Stopped Surrendering Their Phone during Class

\begin{tabular}{|c|l|}
\hline Theme & Representing Concept \\
\hline 1 & Did not care any more about the cell phone activity. \\
\hline 2 & Needed/wanted their phone for personal/family matters or emergencies. \\
\hline 3 & Did not think the extra points would help their grade \\
\hline 4 & Wanted their phone to do other things during the lesson. \\
\hline
\end{tabular}

At the end of the questionnaire, the students were asked to:

"Write an essay related to whether or not you recommend the cellphone activity for future classes and why. You may include in your essay such things as how you believe it affected the classroom atmosphere, how it affected you personally, etc. Please provide a detailed discussion as to why you recommend it or do not recommend it. Your essay may be as long as you like. Please take your time!"

193 students responded to the essay, and $96 \%$ of the responses stated that offering extra credit by surrendering their cellphone was a positive action and that they would recommend the activity to future classes. Two themes emerged from the essay for supporting the activity in future courses, and one theme appeared for not offering the activity in future courses. These themes are presented in table four.

Table4. Themes for Questionnaire Essay.

\begin{tabular}{|c|l|}
\hline Theme Positive & Representing Concept \\
\hline 1 & Keeps me focused, engaged, and improves concentration. \\
\hline 2 & The phone is not a constant distraction to myself or others/class. \\
\hline Theme Negative & Representing Concept \\
\hline 1 & Outside responsibilities dictate the need to keep the phone with the student \\
\hline
\end{tabular}

\section{DISCUSSION}

This study's purpose was to determine if offering positive reinforcement (extra credit) to surrender a cellphone each class would be a positive experience for the student and classroom environment. The results indicate that students felt that not having a cellphone during class was both positive and 
increased focus, engagement, and improved concentration. The students also felt that not having cellphones in the class was a positive activity and changed the classroom atmosphere to be more respectful and focused.

These findings add to the growing body of research that having cellphones in class reduces learning and leads to lower grades (Katz \& Lambert, 2016 \& Gingerich \& Lineweaver, 2014). While prior research has documented the correlation between cellphones in class and lower course grades (Katz \& Lambert, 2016), this study showed that not having cellphones in class benefits class climate, enjoyment, and respectfulness toward the instructor. These qualities all lead to a more beneficial learning environment that allows the student to engage with other classmates and the instructor. This type of engagement in the classroom has been lost in the last decade due to distraction (Ellis, Daniels, \& Jauregui, 2010; Gingerich \& Lineweaver, 2014) and in this study, the students indicated that not having cellphones in class increases the positive atmosphere for learning.

Cellphone addiction is a real phenomenon (Gardiner, 2016) that causes distraction and feelings of anxiety when a person can't access his/her phone. Offering a positive reinforcement was suggested as a way that can offset these adverse feelings when surrendering one's phone (Katz \& Lambert, 2016). The findings of this study support this approach. Students overwhelmingly responded positively and would recommend it to future classes. This was supported in the opened ended essay question with $96 \%$ of the students supporting the activity. However, having a policy in place that allows students access to their phones to contact baby-sitters or family members when needed is important. It is evident that cellphones should be limited in classrooms and positive reinforcement offers an alternative to an outright ban. This study shows that students want a cellphone-free classroom, and feel strongly that it helps create an environment where class discussion and atmosphere are improved.

\section{APPENDIX A}

Circle your answer for each question below.

1. Overall, how do you feel about the cellphone extra credit activity we did this semester?

I loved it

I liked it

I didn't care one way or the other

It was not a particularly good idea, in my opinion

I hated it

2. Do you feel it had an overall positive effect on the classroom atmosphere in general?

Yes, a big positive effect on classroom atmosphere

Yes, a little positive effect on classroom atmosphere

No

Not sure

3. Indicate how often you participated (in class sessions that you attended).

Every class session

Almost every class session

Most class sessions

Very few or no class sessions

4. Did the class participating in the cellphone extra credit help you concentrate better on classroom activities?

Yes, I was able to concentrate a lot better in class

Yes, I was able to concentrate a little better in class

No

Not sure 
5. Did you feel the class participating in the cellphone extra credit changed the classroom atmosphere to be more focused?

Yes, much more focused

Yes, a little more focused

No

Not sure

6. Did you feel the class participating in the cellphone extra credit changed the classroom atmosphere to be more respectful?

Yes, a lot more respectful

Yes, a little more respectful

No

Not sure

7. Why do you think students stopped putting their cellphones on the front desk before class started during the last couple of weeks of the semester? (If this question doesn't apply to your class, skip this question.)

They thought they had enough extra credit

They had more urgent text messages they were expecting due to it being the end of the semester

They were bored by the activity after the whole semester

Other

8. Would you recommend this activity for future classes?

Yes, it was awesome

Yes, it was good

No

Absolutely not, it was awful

Not sure

Essay Related to Cell PHONe ACTIVITy

Write an essay related to whether or not you recommend the cellphone activity for future classes and why. You may include in your essay such things as how you believe it affected the classroom atmosphere, how it affected you personally, etc. Please provide a detailed discussion as to why you recommend it or do not recommend it. Your essay may be as long as you like. Please take your time!

\section{REFERENCES}

[1] American Psychological Association (2017). Stress in American: Coping with Change. Stress in America Survey.

[2] Barnwell, P. (2016, April). Do Smartphones Have a Place in the Classroom? The Atlantic.

[3] Berry, M. \& Westfall, A. (2015). Dial D for Distraction: The Making and Breaking of Cell Phone Policies in the College Classroom. Journal of College Teaching. 63(2). pp 62-71.

[4] Burak L. (2012). Multitasking in the university classroom. International Journal for the Scholarship of Teaching and Learning, 6, Article 8.

[5] Cohan, D. (2016). Cell Phones and College Students. Psychology Today. Retrieved September 15, 2017.

[6] Duncan D. K., Hoekstra A. R., Wilcox B. R. (2012). Digital devices, distraction, and student performance: Does in-class cell phone use reduce learning? Astronomy Education Review, 11, 1-4.

[7] Elhai, J. D., Dvorak, R. D., Levine, J. C., \& Hall, B. J. (2017). Problematic smartphone use: a conceptual overview and systematic review of relations with anxiety and depression psychopathology. Journal of Affective Disorders, 207, 251-259

[8] Ellis, Y., Daniels, B. \& Jauregui, A. (2010). The Effect of Multitasking on the Grade Performance of Business Students. Research in Higher Education Journal.

[9] Gardiner, S. (2016, April 26). The Student Cellphone Addiction is No Joke. Education Week. Retrieved from: https://www.edweek.org/ew/articles/2016/04/27/the-student-cellphone-addiction-is-no-joke.html 
[10] Gingerich, A. \& Lineweaver, T. (2014). OMG! Texting in Class = U Fail :( Empirical Evidence That Text Messaging During Class Disrupts Comprehension. Teaching of Psychology. 41(1). pp 44-51.

[11] Katz, L. \& Lambert, W. (2016). A Happy and Engaged Class Without Cell Phones? It's Easier Than You Think. Teaching of Psychology. 43(4) 340-345.

[12] Kowalski, K. (2016, March 3). When Smartphones Go To School. Science News for Students. Retrieved from: https://www.sciencenewsforstudents.org/article/when-smartphones-go-school

[13] Kuznekoff, J., Munz, S., \& Titsworth, S. (2015). Mobile Phones in the Classroom: Examining the Effects of Texting, Twitter, and Message Content on Student Learning. Communication Education. 64:3, 344-365. DOI: $10.1080 / 03634523.2015 .1038727$

[14] McCoy, B. (2013). Digital Distractions in the Classroom: Student Classroom Use of Digital Devices for Non-Class Related Purposes. Journal of Media Education. Vol. 4. \#4. pp5-14.

[15] McDonald S. E. (2013). The effects and predictor value of in-class texting behavior on final course grade. College Student Journal, 47, 34-40.

[16] Ormiston, M. (2016). How to Use Cell Phones as Learning Tools. Retrieved September 25, 2016, from http://www.teachhub.com/how-use-cell-phones-learning-tools

[17] Roberts, J. \& Davids, M. (2016). My life has become a major distraction from my cell phone: Partner phubbing and relationship satisfaction among romantic partners. Computers in Human Behavior. Vol. 54. Pp134-141.

[18] Song, J. \& Blume, H. (2015, October 29). How other teachers might have handled the texting South Carolina teen. Retrieved from: http://www.latimes.com/local/education/la-na-teacher-discipline-20151029story.html

[19] Thomas, K.M., O’Bannon, B. W., \& Bolton. N. (2013). Cell Phones in the Classroom: Teachers' Perspectives of Inclusion, Benefits, and Barriers. Computers in the Schools: Interdisciplinary Journal of Practice, Theory, and Applied Research. Vol. 30. Iss. 4. pp 295-308.

[20] Thomas, K.M., O’Bannon, B.W., Britt, V.G. (2014). Standing in the Schoolhouse Door: Teacher Perceptions of Mobile Phones in the Classroom. Journal of Research on Technology in Education. Vol 46(4). pp 373-395.

[21] Traxler, J. (2009). Learning in a Mobile Age. International Journal of Mobile and Blended Learning. Vol. 1(1). pp 1-12. DOI: $10.4018 / \mathrm{jmbl} .2009010101$

\section{AUTHORS' BIOGRAPHY}

Dr. Sandy Kimbrough is an associate professor and her research interests include excellence in teaching and teacher preparation. Dr. Kimbrough has served on the TAHPERD Board as the VP of Recreation and College divisions.

Dr. Dean Culpepper is an assistant professor and Certified Mental Performance Consultant. His research interests include teacher preparation, sport moral reasoning, and physical activity.

Tanner Crutcher is a graduate assistant for research. His area of research is in classroom performance.

Citation: Kimbrough, $S$ et al. "Students' Perception of Cell Phones in the Classroom." International Journal of Humanities Social Sciences and Education (IJHSSE), vol 4, no. 11, 2017, pp. 147-152. doi:http://dx.doi.org/10.20431/2349-0381.0411016.

Copyright: (C) 2017 Authors. This is an open-access article distributed under the terms of the Creative Commons Attribution License, which permits unrestricted use, distribution, and reproduction in any medium, provided the original author and source are credited. 